\title{
Rekonstrukcja części ołtarzowej cerkwi Zwiastowania NMP w Supraskiej Ławrze
}

\author{
Adam Musiuk \\ Politechnika Białostocka, Wydział Architektury, Pracownia Technicznego Wspomagania Projektowania \\ Polska \\ adam.musiuk@wp.pl
}

Adam Musiuk, Reconstruction of the sanctuary of the Annunciation Church in Suprasl Lavra, Elpis, 18 2016: 171-175.

\begin{abstract}
Reconstruction of the XVI century church of the Annunciation of the Mother of God of the Suprasl Laura enters now the period of the reconstruction of the interior décor. Due to the lack of sufficient number of historical materials decisions concerning the design must be taken based on hypotheses and comparative analysis. In the work, solutions of the question of the program of frescoes in the sanctuary as well as the altar were suggested.
\end{abstract}

Streszczenie: Rekonstrukcja pochodzącej z XVI wieku cerkwi Zwiastowania NMP znajdującej się w Supraskiej Ławrze wchodzi obecnie w okres odtwarzania jej wnętrza. Z powodu sprzeczności i braku wystarczającej liczby materiałów historycznych decyzje projektowe należy podjąć na podstawie hipotez i analizy porównawczej. W pracy zaproponowano rozwiązania dotyczące programu fresków części ołtarzowej oraz ołtarza.

Keywords: reconstruction, fresco, church

Słowa kluczowe: rekonstrukcja, fresk, cerkiew

\section{Wstęp}

We wzniesionej w latach 1503-1511 $1^{1}$, zburzonej w $1944^{2}$ roku, rekonstruowanej zaś od $1984^{3}$ roku cerkwi Zwiastowania NMP wchodzącej w skład Supraskiej Ławry, zespół projektowy stoi obecnie przed zadaniem odtworzenia wystroju wnętrza i wyposażenia. Jest to zadanie bardzo trudne, gdyż najważniejsze archiwalia dotyczące supraskiej cerkwi są dość skąpe i w wielu przypadkach sprzeczne ${ }^{4}$. Z tego tė̇ względu rekonstrukcję wnętrza często trzeba będzie oprzeć na hipotezach i analizie porównawczej. Dodatkowo, jak dotąd żaden z badaczy w sposób szerszy nie zaproponował programu prac rekonstrukcyjnych, a główny nacisk w pracach naukowych był kładziony na badania i analizy historyczne nie transponowane na trwającą obecnie rekonstrukcję. W pracy podejmiemy więc próbę wskazania kierunków rekonstrukcji, jednak ze względu na bardzo szeroki zakres tematu, zawęzimy ją jedynie do fresków części ołtarzowej i samego ołtarza.

\footnotetext{
Archieograficzeskij sbornik dokumientow, otnosiaszczichsia $k$ istorii Siewier-Zapadnoj Rusi, izdawajemyj pri uprawlenii Wilenskogo Uczebnogo Okruga, t. IX, Wilno 1870, s. 3-4.

2 Mironowicz A., Życie monastyczne na Podlasiu, Białoruskie Towarzystwo Historyczne, Białystok 1998, s. 29.

3 Kronika Parafii Zakonnej Zwiastowania NMP i św. Jana Teologa w Supraślu, t. I.

4 Por. Mironowicz A., O początkach monasteru supraskiego i jego fundatorach, Monaster Zwiastowania NMP w Supraślu, Supraśl 2013.
}

\section{Założenia programu rekonstrukcji}

Założeniem rekonstrukcji cerkwi Zwiastowania Bogarodzicy było odwołanie się do pierwotnego, pochodzacego z XVI wieku, jej wizerunku ${ }^{5}$. Takie samo więc założenie należy przyjąć dla części ołtarzowej. Jest pewnym, że była to najwcześniej uporządkowana architektonicznie przestrzeń świątyni, gdyż jest to warunek konieczny do sprawowania Świętej Liturgii. Jednocześnie, mimo tak wielkiej wagi prezbiterium w strukturze świątyni, zaskakującym jest fakt, że dysponujemy bardzo skapą wiedzą zawartą w materiałach historycznych na jego temat. Najobszerniejsze źródło historycznych fotografii, na którym w dużej mierze oparto rekonstrukcję bryły cerkwi, czyli przeprowadzona na początku XX wieku inwentaryzacja Piotra Pokryszkina ${ }^{6}$, w sposób bardzo ograniczony pokazuje część ołtarzową. Możemy tam, co prawda, odszukać fotografie części ołtarzowej, jednak obrazują one ówczesny wystrój, całkowicie zmieniony w stosunku do pierwszego, z XVI wieku. Pierwotne rozwiązania są całkowicie przesłonięte lub w czasie wykonania fotografii zostały już zastąpione innymi, nowszymi. Drugie źródło historyczne, na którym większość badaczy opiera

\footnotetext{
5 komunikat prywatny przekazany w 1993 roku przez abp Mirona (Chodakowskiego) ówczesnego archimandrytę Klasztoru Męskiego Zwiastowania NMP w Supraślu nadzorującego rekonstrukcję cerkwi w latach $1984-1998$.

6 Pokryszkin P., Błagowieszczenskaja cerkow w Suprasl'skom Monastyre, [w:] Sbornik archieograficzeskich statiej podniesiennych grafu A. A. Bobrinskomu, Sankt Petersburg 1911, s. 222-237.
} 
swoje badania, spisana w końcu XIX wieku przez archimandrytę Mikołaj Dałmatowa historia Supraskiej Ławry ${ }^{7}$, jedynie w kilku, nielicznych miejscach zawiera wzmianki, z których można wyciągnąć pojedyncze wnioski o wyglądzie części ołtarzowej. Taki stan rzeczy zmusza nas do oparcia programu rekonstrukcji wystroju części ołtarzowej na bardzo szerokiej analizie różnego rodzaju materiałów historycznych dotyczących Supraskiej Ławry. Przydatne też tu będą pozycje współczesnych badaczy, których jak już nadmieniono zainteresowania przede wszystkim skupiają się na dociekaniach historycznych, jednak pozwalają też na wyciągnięcie wniosków pomocnych przy rekonstrukcji.

\section{Rekonstrukcja fresków}

Najbardziej znanym zabytkiem supraskiej cerkwi są jej freski. Ich odtworzenie uznać należy za kluczowe. Po wysadzeniu cerkwi ocalała zaledwie niewielka część fresków. Udało się jedynie uratować 30 stosunkowo dużych fragmentów o łącznej powierzchni około $33 \mathrm{~m}^{2}$. Zabezpieczono też niewielkie okruchy, które stały się podstawą badań petrologicznych. Oczywistym też źródłem wiedzy o freskach jest, wspominana wcześniej, inwentaryzacja Pokryszkina.

Fundamentalnym jest tu wskazanie autora supraskich fresków, gdyż otwiera nam to szeroką bazę materiałów porównawczych. Autorstwo to badacze przypisują Serbowi Nektariuszowi. Z lakonicznego wpisu w rejestrze wypłat zawartym w Kronice Ławry Supraskiej pod datą 1557: Serbinu Nektariju malerju za Deisusec teploe cerkvi dano 6 kop groszej, a zoloto cerkovnoe. Za dve svjatosti, sto on ze robil, trech svjatitelej $i$ trech prepodobnych 9 kop groszej a zoloto cerkovnoe. ${ }^{8}$ wynika, że w tym czasie w Supraślu przebywał serbski malarz. Wykonał on trzy ikony, z których jedna przeznaczona była do tak zwanej ciepłej cerkwi, czyli cerkwi pod wezwaniem św. Jana Teologa oraz dwie pozostałe, najprawdopodobniej, do tak zwanej zimnej cerkwi, czyli cerkwi Zwiastowania Bogarodzicy. W samym rejestrze nie mamy jednak żadnych informacji o jakichkolwiek wypłatach za wykonanie fresków cerkwi. Uwaga badaczy skupiła się wokół Serbina Nektaria, ponieważ z jednej strony, często na ziemiach ruskich ci sami mistrzowie byli twórcami ikon i malowideł ściennych, ale z drugiej, być może i dlatego, że żadnej innej alternatywy autorstwa supraskich fresków jak dotąd nie odnaleziono. Samo imię niewiele jednak nam mówi, gdyż na podstawie supraskich archiwaliów nie można powiedzieć, kim ów „Serbin Nektarij Malar” był. Tu w historii pojawia się postać arcybiskupa ochrydzkiego, a później wołogodzkiego Nektariusza, któremu znany rosyjski badacz Petrov już w XIX wieku przypisał autorstwo ${ }^{9}$

Dałmatow N., Suprasl'skij Błahowieszczenskij Monastyr, Sankt Petersburg 1892.

8 Archieograficzeskij sbornik..., s. 52.

9 Petrov N., „Tipik” o cerkovnom i o nastennom pisme episkopa Nektarija iz grada Velesa, 1599 goda i znacenie ego v istorii russkoj ikonopisi, [w:] Zapiski Imperatorskago Russkago Archeologiceskago Obscestva, t. XI, Sankt Peterburg 1899, s. 1-52. podręcznika malarskiego Tipika ${ }^{10}$ z 1599 roku, który był szeroko stosowany na Bałkanach. Badacze tu podzielili się na dwie grupy. Pierwsza grupa, między innymi Swetozar Radojcic $^{11}$, czy Petrov stwierdza, że jest tu mowa o dwóch różnych malarzach: autorze supraskich fresków Nektariuszu i abp Nektariuszu autorze Tipika. Druga grupa, między innymi Sreten Petkovic ${ }^{12}$, czy Stanisław Stawicki ${ }^{13}$, stawia tezę, że Nektariusz, autor supraskich fresków i autor Tipika to ta sama osoba, a jedynie błędnie jego imię zestawiono $\mathrm{z}$ abp Nektariuszem. Jako nierozstrzygniętą tę kwestię zostawia Stanisław Szymański ${ }^{14}$, konkludując, że temat ten wymaga jeszcze dodatkowych badań. Dzisiaj, w kontekście rekonstrukcji fresków, najważniejszy jest jednak fakt, iż nawet jeśli autor supraskich fresków, nie był autorem Tipika, to jednak ich warsztat był tożsamy, ponieważ analizując na podstawie zachowanych fragmentów technikę i technologię wykonania supraskich fresków dochodzimy do wniosku, że zostały one wykonane zgodnie z wskazówkami Tipika ${ }^{15}$.

Warto w tym miejscu zwrócić uwagę na wnioski przed-

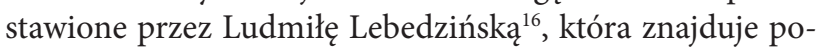
dobieństwo zachodzące między zachowanymi reliktami w Supraślu, a freskami znajdujących się we wschodniej Serbii, w cerkwiach monasterów w Ravanicy (II połowa XIV w.), Kalenicy (XV w.), Ljubostiniji (1402-1405 r.) i przede wszystkim Manasiji (1418 r.). Duże podobieństwo między stylem fresków z Supraśla i z Manasiji wskazuje także rosyjski badacz Aleksander Rogow ${ }^{17}$. Do ciekawych wniosków dochodzi Szymański przedstawiając kolejne cerkwie jako prawzory ornamentów wykorzystanych w supraskiej świątyni ${ }^{18}$. Największą liczbę powiązań ornamentalnych znajduje on z freskami cerkwi w Decani (1348-1350 r.) oraz Treskavacu (XIV w.). Są to cerkwie dalekiego południa Serbii, zapewne będące $\mathrm{w}$ bezpośrednim oddziaływaniu Ochrydu. Dodatkowo, Szymański wskazuje podobieństwo, ale w mniejszym już stopniu, supraskich ornamentów do ornamentów cerkwi w Sopocani (1205 r.), Studenicy (1314 r.), Starej Pavlicy (XII w.), Milesevie (1227-1232 r.), Arilje (1300 r.), Prizreniu (1307-1310 r.), Rudenicy (1410 r.), Lesnovie (1349r.), Nowej Pavlicy (koniec XIV w.), Gracanicy $(1318$ - 1321 r.). Te z kolei miejsca skupiają się w centralnej i południowej części Serbii. Niektórzy badacze, między in-

\footnotetext{
10 „Tipik” o cerkvenom i zidnom slikanu Nektarija Srbina 1599, [w:] Medit M., Stari slikarski prirucznicy, t. II., Beograd 2002, s. 216-288.

11 Radojcić S., Majstori starog srpskog slikarstva, Beograd 1955, s 77-78.

12 Petkovic S., Nektarij Serb, malarz z XVI wieku i jego działalność w klasztorze w Supraślu, [w:] Rocznik Białostocki, t. XVI, Warszawa 1991, s. 293-323.

13 Stawicki S., Malowidła ścienne dawnej cerkwi Zwiastowania NMP w Supraślu - problemy techniczne i technologiczne, [w:] Biuletyn Konserwatorski Województwa Podlaskiego. Wojewódzki Urząd Ochrony Zabytków w Białymstoku, Białystok 2004, s. 7-43.

14 Szymański S., Freski z Supraśla, próba rekonstruowania genealogii,

[w:] Rocznik Białostocki, t. IX, Białystok 1972, s. 161-182.

15 Zob. Stawicki S., Malowidła ścienne..., s. 7-43.

16 Freski z Supraśla, Katalog wystawy, oprac. Lebedzińska L., Białystok 1968.

17 Rogow A., Freski Supraslja, [w:] Drevnierusskoe iskusstvo. Monumentalnaja żivopis XI-XVII ww., Moskwa 1980, s. 345-371

18 Szymański S., Freski z Supraśla..., s. 169-176.
} 
nymi Antoni Mironowicz ${ }^{19}$, czy Szymański ${ }^{20}$, wskazują na możliwość zdobywania przez jakiś czas umiejętności malarskich przez Nektariusza, na Świętej Górze Athos, w znajdującym się tam serbskim monasterze Chilandar. Analiza fresków wymienionych wyżej cerkwi wskazuje na wiele ich cech powtarzalnych. Zarówno program, jak i sam styl wykonania wykazują wiele cech wspólnych. Z punktu widzenia rekonstrukcji, na podstawie analizy porównawczej otrzymujemy więc zestaw cennych wskazówek przydatnych przy tworzeniu programu rekonstrukcji.

Zwróćmy też uwagę, na sytuację nietypową dla Nektariusza. Otóż wielce prawdopodobne jest, że w Supraślu po raz pierwszy spotkał się on z koniecznością wykonania bizantyjskich fresków w przestrzeni świątyni późnogotyckiej. Analogiczne świątynie pod względem architektury możemy spotkać jednie na terenie obecnej Białorusi, natomiast pod względem malarstwa analogii możemy szukać od Budapesztu na północy, aż po Saloniki i Świętą Górę Athos na południu. Kluczem do rozwikłania tej trudności wydaje się więc próba zrozumienia, jak przy tworzeniu fresków Nektariusz wykorzystał zastaną przestrzeń świątyni mając wiedzę i doświadczenie z obszaru Bałkanów.

Reasumując, program rekonstrukcji fresków zaproponowany zostanie w oparciu o: Tipik, analizę porównawczą części ołtarzowych bałkańskich cerkwi, w których odnaleziono podobieństwa $\mathrm{z}$ supraskimi freskami oraz analogię do zapisanych w historycznych fotografiach innych części supraskiej świątyni. Z analizy tej wynika, iż wydaje się oczywistym, że w dolnej strefie ścian części ołtarzowej pomiędzy oknami powinny znajdować się ornamenty, analogiczne do tych które spotykamy w całej głównej nawie cerkwi. W zastanej architekturze ołtarza, między innymi ze względu na stosunkowo duże otwory okienne ściany wschodniej, na ścianach północnej i południowej musiał być zlokalizowany fresk, występujący we wskazywanych wcześniej cerkwiach Serbii nazywany, Служба архијереја („Służba świętych hierarchów”). Natomiast sklepienie konchowe absydy stwarza możliwość dla umieszczenia tu wizerunku Bogarodzicy w postaci Orantki - Ширшаја Небеса („Szersza Niebios”). Potencjalne medaliony z wizerunkami świętych były opatrzone ornamentami, które znamy z nawy głównej. Można też założyć, iż nad ołtarzem znalazły się wyobrażenia cherubinów, a pas cokołowy całej części ołtarza pokrywał rysunek zasłony, na co wskazuje logika zagospodarowania przestrzeni.

\section{Rekonstrukcja ołtarza}

Podobnie jak w przypadku fresków supraskiej cerkwi Zwiastowania Bogarodzicy, niewiele wiemy o pierwszym wyposażeniu części ołtarzowej i jego najważniejszym elemencie: ołtarzu (ros. prestot). Analizę w tym miejscu, musimy więc oprzeć na porównaniu z innymi ołtarzami z tego

\footnotetext{
19 Por. Mironowcz A., Związki monasteru supraskiego ze Świętą Góra Athos w XVI wieku, [w:] Święta Góra Athos w kulturze Europy, pod redakcją Kuczyńskiej M., Gniezno 2009, s. 117-127.

20 Szymański S., Freski z Supraśla..., s. 180.
}

okresu, zarówno na terenie Podlasia, jak i Bałkan. Możemy też odwołać się do obecnych ołtarzy, gdyż współcześnie stawiane są takie same wymagania teologiczne, jak w czasie budowy supraskiej cerkwi. Należy też zwrócić uwagę, iż cała świątynia, a w szczególności jej ikonografia, miała stać na straży czystości wiary prawosławnej ${ }^{21}$. Takiego samego założenia powinniśmy się spodziewać także, a może nawet w szczególności, przy wykonaniu części ołtarzowej.

Przy założeniu, iż monaster utrzymywał kontakty ze św. Górą Athos ${ }^{22}$, a część braci wręcz mogła przybyć z tego $\operatorname{miejsca}^{23} \mathrm{z}$ dużą dozą prawdopodobieństwa możemy założyć, iż część ołtarzowa świątyni wykonana była w zgodzie $\mathrm{z}$ traktatem mistagogicznym bł. Symeona z Tessaloniki. Obok Mystagogica św. Maksyma Wyznawcy ${ }^{24}$, Historia Ecclesiastica św. Germana ${ }^{25}$, Sacrae liturgiae interpretatio Mikołaja Kabasilasa ${ }^{26}$ dwa teksty bł. Symeona De sacra liturgia ${ }^{27}$ oraz Expositio de divino templo ${ }^{28}$ (polskie tłumaczenie: $O$ świątyni Bożejej) są uważane za najlepszy wykład katechetyczny najważniejszych dla Świętej Eucharystii symboli, między innymi związanych z przestrzenią sakralną. Duża popularność tekstów bł. Symeona z Tessaloniki w okresie budowy supraskiej cerkwi zapewnia, iż budowniczowie musieli odwoływać się do zasad przywoływanych w nich. Symeona. Jeśli nawet nie były to odwołania wprost - gdyż traktaty bł. Symeona nie były znane budowniczym cerkwi Zwiastowania Bogarodzicy - to zapewne oparto się na innych tekstach teologicznych, ale możemy być pewni, że były one tożsame. Ta pewność wynika ze sposobu tworzenia traktatów mistagogicznych we wschodniej tradycji, polegającej w głównej mierze na kompilowaniu wcześniejszych ksiąg.

Przestudiujmy więc składający się ze 103 paragrafów traktat bł. Symeona szukając w nim wskazówek dotyczących ołtarza. Informacje te znajdziemy w paragrafach 5, $10,13,14,15,17,58,80,85,86$ i 90 . Nie znajdujemy tu, co prawda, wprost wskazania wymiarów, czy form ołtarza, ponieważ nie taki cel miały mistagogie - nie są one wszakże podręcznikami dla architektów. Znajdujemy jednak wskazówki, które budowniczowie cerkwi uwzględnić musieli. Przy dość skąpej wiedzy historycznej dotyczącej architektury oraz wystroju części ołtarzowych cerkwi w XVI wieku na terenach, na których znajduje się Supraśl, informacje $\mathrm{z}$ mistagogii zmuszeni będziemy zestawić, także z rozwiązaniami z okresów późniejszych.

Mistagogie wskazują nam na konieczność wykonania ołtarza z kamienia ${ }^{30}$. Taka praktyka właściwie na Podlasiu

\footnotetext{
21 Mironowcz A., Związki monasteru supraskiego..., s. 122-123.

22 Ibidem, s. 117-127.

Mironowicz A., O początkach monasteru supraskiego..., s. 15.

24 PG, 91, 657-718.

25 PG, 98, 381-453.

26 PG, 150, 368-492.

27 PG, 155, 253-304. (w pracy posługiwano się przekładem na język rosyjski: Socinenija błażennogo Simeona, archiepiskopa Fessalonikijskogoi [w:] Pisanija Swjatych Otcow i uczitelej Cerkwi, otnosjaszcziesja k istolkowaniju prawosławnogo bogosłużenija. TKiK, t. 2, Sanktpeterburg 1859).

28 PG, 155, 697-750.

29 Symeon z Tessaloniki, O świątyni Bożej. WUJ, Kraków 2007, s. 33-93.

30 Ibidem, s. 41.
} 
nie jest i nie była stosowana. Generalnie na tym obszarze spotykamy się z ołtarzami wykonanymi z drewna. Współcześnie jedynie cerkiew w Brańsku posiada ołtarz kamienny. Taki stan rzeczy jest zapewne konsekwencją trudności zdobycia budulca. Analizując historyczne materiały z pierwszego okresu funkcjonowania supraskiej cerkwi nie otrzymujemy odpowiedzi na pytanie o rodzaj materiału wykorzystanego do budowy jej ołtarza. Dodatkowo na fotografiach wykonanych po zburzeniu cerkwi nie można dostrzec śladów po ołtarzu - część ołtarzowa jest zasypana gruzem. Nie posiadamy też informacji o odnalezieniu śladów ołtarza w czasie odgruzowywania. Rodzaj materiału, z którego wykonano ołtarz oprzeć więc trzeba na hipotezie.

Cerkiew Zwiastowania NMP była obiektem wyjątkowym. Jej wielkość, sposób wyposażenia wymagał olbrzymich nakładów. Ten rozmach pozwala sądzić, że przyjmując program jej wyposażenia zadbano o każdy szczegół, nie idąc na kompromisy wynikające z braku środków finansowych. Dodatkowo, należy pamiętać o, przytoczonej już wcześniej, konieczności wybudowania świątyni całkowicie zgodnej z kanonami Cerkwi prawosławnej, a więc i zgodnej z mistagogiami. Dlatego należy przyjąć za wielce prawdopodobne, że ołtarz był wykonany z kamienia. Dodatkowo utwierdza nas $\mathrm{w}$ tym fakt szerokich kontaktów monasteru supraskiego z prawosławnym południem Europy, gdzie występowanie kamiennych ołtarzy było częste.

Podobne wnioski należy wyciągnąć rozważając wskazywane przez bł. Symeona z Tessaloniki podwyższenie, na którym ołtarz powinien się znajdować i umieszczony nad nim baldachim. O konieczności umieszczenia ołtarza na podwyższeniu, oprócz przytoczonego już paragrafu 17 Expositio de divino templo, czytamy także w rozdziale 133 De sacra liturgia: : „Święty Stół ${ }^{31}$ jest czworokątny dlatego, że z niego spożywali i teraz spożywają cztery strony świata; unosić się [na podwyższeniu] powinien z powodu Przenajświętszego i Arcyniebiańskiego Sakramentu"32. Takie podwyższenie w formie schodów istniało już w Świątyni Mądrości Bożej, o czym czytamy w traktacie Kodinosa De officialibus palatii Constantinopolitani: „Wokół Świętego Stołu Justynian zbudował złote schody, na które wchodzili

\footnotetext{
31 Ołtarz, ros. prestol.

32 Cytat za: Nowe tablice czyli o cerkwi, liturgii, nabożeństwach $i$ utensyliach cerkiewnych. Objaśnienia Beniamina arcybiskupa Niżnego Nowogrodu i Arzamasu. WUJ, Kraków 2007, s. 18.
}

kapłani aby ucałować Święty Stół" ${ }^{33}$. W rozdziale 139 De sacra liturgia przedstawione są informacje o znajdującym się nad Świętym Stołem baldachimie: „Nad Boskim Świętym Stołem wznoszony święty pokrowiec (baldachim) oznacza niematerialny namiot Boży, to jest chwałę Bożą i Łaskę, którą pokrywa się Sam przywdziewający światło jako szatę i zasiadający na wywyższonym Tronie Chwały Swojej" ${ }^{34}$. Podobnie jak w przypadku wykorzystania kamienia do wznoszenia ołtarzy, także stosowanie baldachimów jest rzadko spotykane na Podlasiu, w przypadku supraskiej cerkwi należy jednak przyjąć taką możliwość za dopuszczalną.

Reasumując, przy przyjęciu programu rekonstrukcji części ołtarzowej należy rozważyć wykonanie znajdującego się na podwyższeniu kamiennego ołtarza, ze znajdującym się nad nim baldachimem. Takie rozwiązanie wydaje się być najwierniejszym odtworzeniem pierwotnej jego formy.

\section{Podsumowanie}

Odbudowywana cerkiew Zwiastowania NMP obecnie wkroczyła w fazę rekonstrukcji wnętrza. Odtworzenie części ołtarzowej to zadanie trudne ze względu na ubogą bazę materiałów historycznych. W takim wypadku program rekonstrukcji, w dużej mierze, oprzeć należy na hipotezach $\mathrm{i}$ analizie porównawczej. Proponuje się więc w zakresie fresków części ołtarzowej na sklepieniu wykonać wizerunek Bogarodzicy w postaci Orantki, na ścianach północnej i południowej zaś umieścić, występujący w bałkańskich cerkwiach podobnego okresu, fresk Служба архијереја. Zgodnie $\mathrm{z}$ logiką zagospodarowania przestrzeni uzupełnieniem powinny być medaliony $\mathrm{z}$ wizerunkami świętych, wyobrażenia cherubinów, międzyokienne ornamenty oraz zasłona części cokołowej. Ołtarz proponuje się wykonać jako kamienny, na podwyższeniu, ze znajdującym się nad nim baldachimem. Rozwiązanie pozostałych elementów wystroju części ołtarzowej należy oddzielnie przeanalizować, jednak kierunki tej analizy będą zbieżne $\mathrm{z}$ zaznaczonymi w pracy.

Artykuł opracowany w ramach pracy statutowej S/WA/2/2016

\footnotetext{
33 Ibidem, s. 19.

34 Ibidem, s. 25.
}

\section{Bibliografia}

Archieograficzeskij sbornik dokumientow, otnosiaszczichsia $k$ istorii Siewier-Zapadnoj Rusi, izdawajemyj pri uprawlenii Wilenskogo Uczebnogo Okruga, t. IX, Wilno 1870

Dałmatow N., Suprasl'skij Błahowieszczenskij Monastyr, Sankt Petersburg 1892

Freski z Supraśla, Katalog wystawy, oprac. Lebedzińska L., Białystok 1968
Kronika Parafii Zakonnej Zwiastowania NMP i św. Jana Teologa $w$ Supraślu, t. I.

Mironowicz A., Życie monastyczne na Podlasiu, Białoruskie Towarzystwo Historyczne, Białystok 1998

Mironowcz A., Związki monasteru supraskiego ze Świętą Góra Athos w XVI wieku, [w:] Święta Góra Athos w kulturze Europy, pod redakcją Kuczyńskiej M., Gniezno 2009 
Mironowicz A., O początkach monasteru supraskiego i jego fundatorach, Monaster Zwiastowania NMP w Supraślu, Supraśl 2013

Nowe tablice czyli o cerkwi, liturgii, nabożeństwach i utensyliach cerkiewnych. Objaśnienia Beniamina arcybiskupa Niżnego Nowogrodu i Arzamasu. WUJ, Kraków 2007

Patrologia Graeca, ed. Migne J.P., Paris 1865-6, vol. 91, 98, 150, 155

Petkovic S., Nektarij Serb, malarz z XVI wieku i jego działalność w klasztorze w Supraślu, [w:] Rocznik Białostocki, t. XVI, Warszawa 1991

Petrov N., „Tipik” o cerkovnom i o nastennom pisme episkopa Nektarija iz grada Velesa, 1599 goda i znacenie ego v istorii russkoj ikonopisi, [w:] Zapiski Imperatorskago Russkago Archeologiceskago Obscestva, t. XI, Sankt Peterburg 1899
Pokryszkin P., Błagowieszczenskaja cerkow w Suprasl'skom Monastyre, [w:] Sbornik archieograficzeskich statiej podniesiennych grafu A. A. Bobrinskomu, Sankt Petersburg 1911

Radojcić S., Majstori starog srpskog slikarstva, Beograd 1955

Rogow A., Freski Supraslja, [w:] Drevnierusskoe iskusstvo. Monumentalnaja żivopis XI-XVII ww., Moskwa 1980

Stawicki S., Malowidła ścienne dawnej cerkwi Zwiastowania NMP w Supraślu - problemy techniczne i technologiczne, [w:] Biuletyn Konserwatorski Województwa Podlaskiego. Wojewódzki Urząd Ochrony Zabytków w Białymstoku, Białystok 2004 Symeon z Tessaloniki, O świątyni Bożej. WUJ, Kraków 2007 Szymański S., Freski z Supraśla, próba rekonstruowania genealogii, [w:] Rocznik Białostocki, t. IX, Białystok 1972

„Tipik” o cerkvenom i zidnom slikanu Nektarija Srbina 1599, [w:] Medit M., Stari slikarski prirucznicy, t. II., Beograd 2002

Rozmiar artykułu: 0,6 arkusza wydawniczego 